\title{
Bild der Mathematik
}

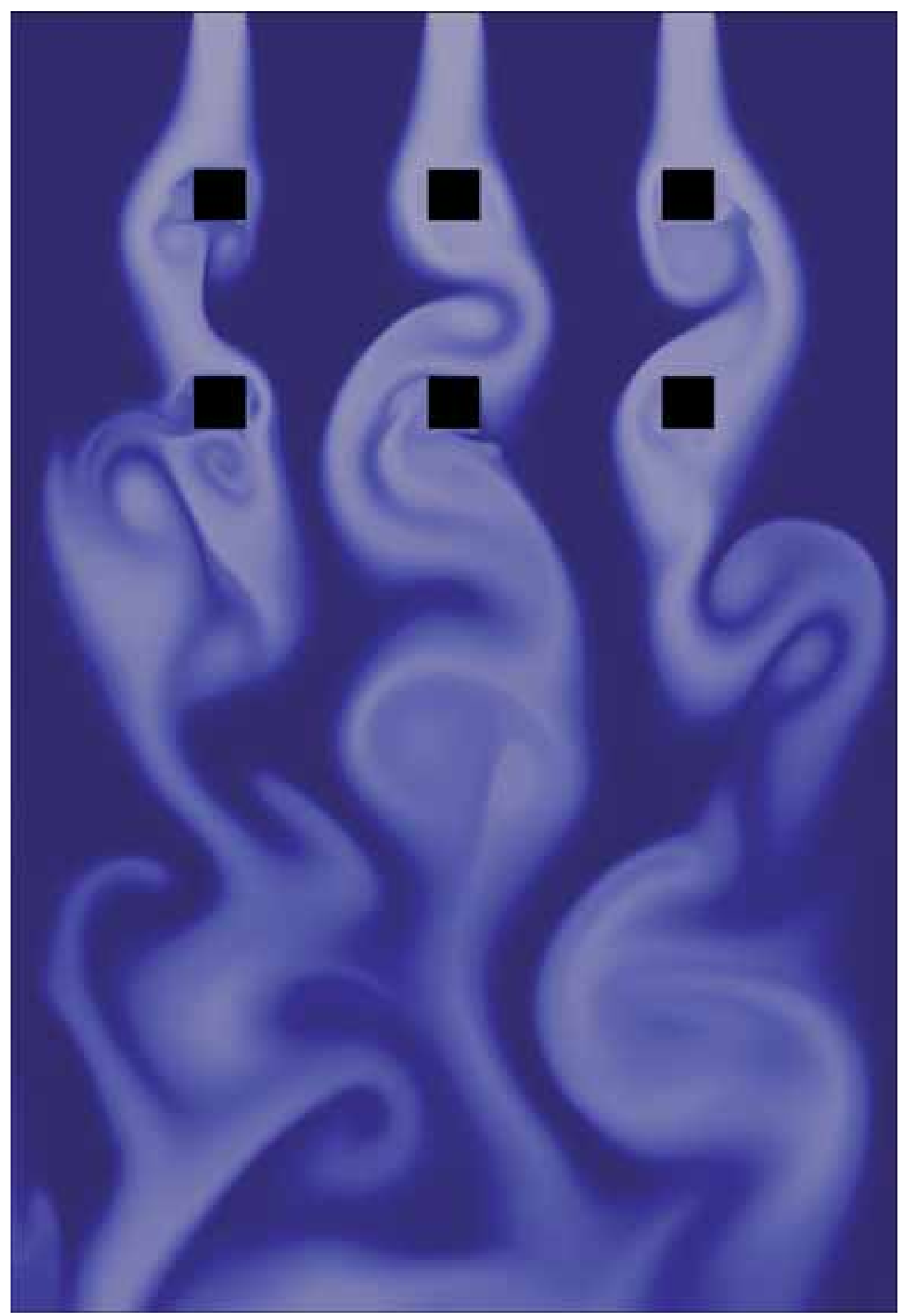

Um die Strömung hinter sechs Pfeilern einer kurzen Brücke über einen Fluß sichtbar zu machen, wurde das Wasser an drei Stellen vor den Pfeilern eingefärbt. Die Simulation mit mehr als 4.65 Millionen Unbekannten im Ort wurde von Jens F. Acker am Lehrstuhl III der TU Dortmund mit Hilfe des Simulationspaketes FEATFLOW durchgeführt. Animationen des Flusses gibt es unter http://featflow.de/en/examples.html zu sehen. 